\title{
KAJIAN PRODUCTION EMPHASIS , PENGEMBANGAN KARIR PROTEAN, DAN KOMPENSASI SOSIAL PADA KINERJA KARYAWAN DENGAN KEPUASAN KERJA SEBAGAI VARIABEL MEDIASI
}

\author{
Oleh \\ Dean Suban Saleh \\ Salman Imbari \\ Karimah \\ Program Studi Akuntansi - STIE DR KHEZ Muttaqien \\ dean.subhan@stiemuttaqien.ac.id \\ Program Studi Manajemen - STIE DR KHEZ Muttaqien \\ salmanimbari@stiemuttaqien.ac.id \\ Program Studi Manajemen - STIE DR KHEZ Muttaqien \\ ima.basalamah@yahoo.com \\ DOI Artikel : https://doi.org/10.34308/eqien.v6i2.94
}

\begin{tabular}{l}
\hline Article Info \\
\hline Article History: \\
Received 31 Juli 2019 \\
Accepted 11 Agustus 209 \\
Available Online 05 September \\
2019
\end{tabular}

Keyword:

Production Emphasis, Carier

Satisfaction,

Performance Employer

\begin{abstract}
One of the success key of a company isincreasing the competitiveness of human resources. The important concept that is recognized as a key for a superior human resources is the right people in the right place at the right time. The low performance from the employer can result in low productivity ( profit) of the company. The performance of employer must be noticed by the company, because the performance of employer can give direct impact in all performance of the company. The motive for this study for test and analyzed the impact of Production Emphasis, the development, the development of Carier Protean and Social Compensation of the performance employer with Job Satisfaction for mediation variabel. The research was conducted on PT. Subang Autocomp Indonesia employer and use multiple regresi linier analysis, SPSS 24 version and path analysis. The result of the study indicate partially the Production Emphasis, Carier Protean development and Social Compensation variabel showing a significant increase in employee performance. And simultan the Production Emphasis, Carier Protean development, and Social Compensation variabel on employee performance mediated by job satisfaction that have a significant effect. While the contribution of variabel and variabel intermediation depends on employee performance by $67 \%$ while the remaining $33 \%$ by other factors
\end{abstract}




\section{PENDAHULUAN}

Kinerja karyawan yang baik dapat terlihat dari kinerja karyawan yang efektif. Rendahnya kinerja karyawan dapat berakibat pada rendahnya produktivitas (laba) perusahaan. Kinerja karyawan menjadi hal yang perlu diperhatikan cukup serius oleh perusahaan, karena kinerja karyawan akan memberikan dampak secara langsung pada kinerja perusahaan secara keseluruhan.

Dengan adanya kinerja akan diketahui seberapa jauh kemampuan seseorang dalam melaksanakan tugasnya. Kinerja adalah tingkat keberhasilan seseorang atau organisasi dalam melaksanakan pekerjaanya. Kinerja haruslah dikelola oleh pimpinan. Seperti apakah kinerja seorang karyawan yang baik dapat didiskusikan dan ditetapkan secara bersama antara karyawan dengan pimpinan.

Menurut Davis dan Newstrom dalam Sinambela (2016:312) mengemukakan bahwa sebagian manajer berasumsi kepuasan kerja yang tinggi selamanya akan menimbulkan prestasi atau kinerja yang tinggi. Namun pada kenyataanya terdapat karyawan yang memiliki kepuasa kerja yang rendah namun memiliki kinerja yang tinggi, dan adapula karyawan yang memiliki kepuasan kerja tinggi namun memiliki kinerja yang rendah.

Kepuasan kerja karyawan berhubungan erat dengan kinerja karyawan. Seseorang yang puas dalam pekerjaanya akan memiliki motivasi, komitmen pada organisasi dan partisipasi kerja yang tinggi sehingga akan terus memperbaiki kinerja mereka. Penelaahan kepuasan kerja karyawan seyogianya dilakukan dengan teratur sehingga dapat dipastikan bahwa mereka dalam kondisi yang puas. Menurut Davis dan Newstrom dalam sinambela (2016: 310), manajer harus berusaha meningkatkan kepuasan kerja karyawannya. Untuk membangun organisasi atau masyarakat yang lebih baik.

Peran pemimpin dalam memotivasi dan mempengaruhi karyawannya juga penting untuk meningkatkan kinerja kayawan. Motivasi dikait - kaitkan dengan istilah urge (desakan), dan drive (dorongan), dimana kedua sifat pemimpin tersebut dapat digunakan sebagai alat untuk meningkatkan kinerja karyawan. Menurut Halpin dalam Soetopo (2010:278) membagi komponen perilaku pemimpin berdasarkan beberapa kategori, salah satunya yaitu : production emphasis atau penekanan pada hasil yaitu mengacu pada perilaku pemimpin agar karyawan bekerja keras misalnya dengan pengawasan ketat, menuntut hasil maksimal. Keberhasilan perusahaan dalam mencapai tujuannya bergantung pada gaya kepemimpinan, yang dapat mempengaruhi perilaku dan sifat karyawannya. Selain itu, pengembangan karier sangatlah penting bagi karyawan maupun perusahaan. Praktik pengembangan karier sebagaimana dikemukakan oleh Bernadin dan Russel dalam Sinambela (2016: 287) dapat meningkatkan kepuasan karier karyawan dan meningkatkan efektivitas perusahaan. Karyawan yang tidak melihat banyak kesempatan untuk maju, atau sama sekali tidak, akan mengalami frustasi yang dapat membawa penurunan komitmen terhadap perusahaan, penurunan kinerja karyawan, dan peningkatan hasrat keluar dari perusahaan.

Karyawan menggunakan pengetahuan, keterampilan, tenaga, waktu, serta komitmennya, bukan semata-mata ingin membaktikan atau mengabdikan diri kepada perusahaan, melainkan tujuan lain yang ingin diraihnya, yaitu mengharapkan imbalan atau jasa atas kinerja yang dihasilkannya. Menurut Michael dan Horold dalam sinambela (2016:223) membagi kompensasi menjadi 3 yaitu : kompensasi material, kompensasi sosial, dan kompensasi aktivitas.

Pemberian kompensasi sosial merupakan salah satu cara perusahaan untuk meningkatkan kinerja karyawan. Karyawan akan bekerja lebih giat dan semangat sesuai dengan apa yang perusahaan harapkan, jika perusahaan memperhatikan dan memenuhi kebutuhan karyawan baik yang bersifat materi maupun kebutuhan non materi. (Sinambela 2016:248) Berdasarkan dari latar belakang yang telah dipaparkan, maka penulis optimis dan tertarik untuk melakukan Kajian mengenai Pengaruh Production Emphasis, Pengembangan Karir Protean, dan Kompensasi Sosial pada Kinerja Karyawan dengan Kepuasan Kerja sebagai variabel Mediasi.

Hal ini didukung dari hasil penelitian yang dilakukan oleh (Sulaida 2010:706) mengenai pengaruh iklim organisasi terhadap kepuasan kinerja karyawan PT. PLN Cabang Lhokseumawe dimana hasil penelitiannya mengemukakan bahwa iklim organisasi yang ditelitinya berdasarkan model Organizational Climate Description Questionare (OCOG) berpengaruh signifikan terhadap kepuasan 
kinerja karyawan,yang berarti dengan adanya iklim organisasi yang baik akan diikuti dengan kepuasan kinerja yang tinggi. Hasil penelitian yang dilakukan oleh (Distyawaty 2017: 66) tentang pengaruh kompetensi dan pengembangan karir terhadap kinerja aparatur pengawasan inspektorat daerah provinsi Sulawesi Tengah dimana dari hasil penelitiannya pengembangan karir berpengaruh secara positif terhadap kinerja aparatur pengawasan inspektorat daerah provinsi Sulawesi Tengah. Yang artinya semakin baik pengembangan karir yang ada di perusahaan maka akan meningkatkan kinerja karyawan yang ada. Usman Fauzi juga melakukan penelitian tentang pengaruh kompensasi terhadap kinerja karyawan pada PT.Trakindo Utama Samarinda dengan hasil penelitiannya bahwa kompensasi finansial dan kompensasi nonfinansial secara simultan berpengaruh signifikan terhadap kinerja karyawan.

\section{KAJIAN PUSTAKA DAN PEGEMBANGAN HIPOTESIS}

Kinerja karyawan atau performance sebagai suatu gambaran mengenai hasil atau tingkat keberhasilan dalam suatu pelaksanaan kegiatan dalam pencapaian tujuan, visi dan misi organisasi yang dituangkan melalui perencanaan strategis suatu organisasi. Kinerja dapat diketahui apabila kita telah menetapkan suatu tolak ukur, dengan adanya tolak ukur kinerja seseorang dapat diketahui tingkat keberhasilannya menurut Moeheriono, dalam Lestari ( 2015:11).

Kinerja adalah seperangkat hasil yang dicapai dan merujuk pada tindakan pencapaian serta pelaksanaan sesuatu pekerjaan yang diminta. Stolovitch dan Keeps dalam Sinambela (2016: 481 ).

Production Emphasis atau penekanan pada hasil yaitu mengacu pada perilaku pemimpin agar staf bekerja keras, misalnya dengan pengawasan ketat, penekanan, direktif, dan menuntut hasil maksimal.Owens, Halpin dalam Soetopo (2010:146)

Production Emphasis merupakan salah satu cara untuk memotivasi karyawan sehingga mampu mencapai tujuan perusahaa. Pemimpin kerap menggunakan penekanan atau memberikan tuntutan kepada bawahannya untuk bekerja secara maksimal agar perusahaan mampu mencapai tujuan nya.
Selain Production Emphasis ada beberapa kompenen perilaku pemimpin yang dikemukakan oleh Ownes, Halpin dalam Soetopo (2010:154), yaitu :

1. Aloofness atau keberjarakan, yaitu menggambarkan kadar perilaku pemimpin yang formal dan impersonal yang menunjukkan jarak sosial dengan staf.

2. Thrust atau rasa yakin, yaitu mengacu pada kadar perilaku pemimpin yang ditandai kerja kerasnya agar dicontoh oleh staf.

3. Consideration atau perhatian, yaitu mengacu pada kadar perilaku pemimpin dengan memperlakukan staf secara manusiawi sesuai dengan martabatnya.

Pengembangan karir adalah upaya yang dilakukan oleh organisasi dalam merencanakan karir pegawainya, yang disebut sebagai manajemen karir, antara lain merencanakan, melaksanakan, dan mengawasi karir. Sinambela ( 2016:260 )

Pengembangan karir adalah peningkatan pribadi yang dilakukan seseorang untuk mencapai rencana karir yang diinginkan. Menurut Handoko dalam Sinambela ( 2016 : 260 )

Pengembangan karir adalah serangkaian aktivitas untuk mempersiapkan seseorang individu pada kemajuan karir yang direncanakan. Mondy dalam Sinambela ( 2016 :260)

Dari beberapa uraian definisi diatas dapat disimpulkan bahwa pengembangan karir adalah rangkaian kegiatan yang dilakukan untuk meningkatkan status jabatan atau mencapai suatu rencana karir yang diinginkan.

Pada hakikatnya, pengembangan karir adalah kewajiban perusahaan dan karyawan itu sendiri. Perusahaan yang maju tentu memiliki struktur organisasi yang jelas dan disosialisasikan kepada seluruh anggota organisasi ( perusahaan ). Menurut kaswan dalam Sinambela (2016 : 253 ) mengatakan mengenai pandangan karir yaitu protean karir. Protean karir adalah nama yang diberikan untuk mendeskripsikan karir yang didorong oleh individu dan bukan oleh organisasi. Karir protean sendiri sering disebut sebagai paradigma perkembangan karir modern.

Kompensasi adalah imbalan jasa atau balas jasa yang diberikan oleh organisasi kepada para tenaga kerja karena tenaga kerja tersebut telah memberikan sumbangan tenaga dan pikiran demi kemajuan organisasi guna mencapai 
tujuan yang telah ditetapkan. Baik dari segi prosedur pekerjaan dan lingkungan kerja. Sastrohadiwiryo dalam Sinambela (2016 : 218 ). Banyak peneliti yang menyimpulkan bahwa pekerjaan (job) dan khususnya karir saat ini berbeda dengan beberapa dekade yang lalu (Cappeli, 1999). Pendekatan lama atau tradisional, yang disebut career jobs, didefinisikan sebagai pekerjaan yang full-time dengan masa kerja yang lama, pembayaran gaji yang layak, menawarkan manfaat, dan mencerminkan perhatian kebijakan umum tentang apakah pekerjaan memberikan solusi untuk menghindari kesulitan ekonomi (Jacoby, 1999), namun pengertian ini sedikit demi sedikit terkikis dengan pergeseran kebutuhan pasar dan perubahan dunia bisnis.

Hall \& Moss (1998) Protean Career didiskripsikan sebagai suatu proses dimana seseorang, bukan organisasi, yang mengatur dimana orang yang protean tersebut memiliki pilihan karirnya sendiri dan mencari untuk memenuhi dirinya yang merupakan elemen yang terintegrasi dalam hidupnya, dan kesuksesan yang dicapai adalah kesuksesan internal atau psikologis, dan bukan eksternal.

Dengan nada yang sama, Waterman dkk. (1994) mengemukakan career-resilient workforce yang diartikan sebagai sebuah kelompok karyawan yang tidak hanya berdedikasi pada ide dari pembelajaran yang berkelanjutan (continuous learning) tetapi juga menyiapkan diri untuk menghadapi perubahan, bertanggung jawab pada pengaturan karir mereka sendiri, dan yang terakhir adalah mempunyai komitmen terhadap kesuksesan perusahaan.

Berkaitan dengan Pengembangan karir, untuk mencapai sebuah keberhasilan maka karayawan harus dibekali dengan kecerdasan. Kecerdasan ini mendorong karyawan untuk memiliki multi kemampuan dalam menjalankan bisnis. Seperti yang disampaikan oleh Gardner (1983) dalam Mahmood, dkk (2015) bahwa manusia memiliki kecerdasan majemuk (Multi Intelligent). Kecerdasan manusia ini meliputi kecerdasan intelektual, kecerdasan emosional, dan kecerdasan spiritual.

Konsep kecerdasan intelektual digagas kali pertama oleh William Stern pada tahun 1912. Mahmood, dkk (2015:554) merujuk pada Pan (2006), Killic (2015), dan Bell (2014) bahwa kecerdasan intelektual dijadikan sebagai tahap pertama dalam membangun kinerja usaha yang baik, karena di dalamnya mengandung unsur berpikir yang kreatif. Pemikiran yang kreatif ini terbentuk dari wawasan dan pengalaman luas.

Beberapa orang beranggapan bahwa kecerdasan intelektual adalah kecerdasan yang mutlak berasal dari manusia sejak lahir. Kecerdasan intelektual setiap orang berbedabeda. Mereka memiliki tingkat nilai IQ yang berbeda-beda. Pada dasarnya nilai IQ seseorang tidak berubah akan berubah sampai dewasa. Adapun yang berubah adalah tingkat ketajaman analisis dan daya pikir. (Dedeng : 2018)

Kompensasi merupakan sesuatu yang diterima pegawai sebagai penukar atas kontribusi jasa mereka bagi organisasi. Apabila dikelola dengan baik maka kompensasi membantu organisasi mencapai tujuan dan memperoleh, memelihara, dan menjaga pegawai dengan baik. Sebaliknya, tanpa kompensasi yang memadai maka pegawai yang ada saat ini sangat mungkin akan meninggalkan organisasi, dan organisasi akan kesulitan untuk merekrut kembali pegawai yang sesuai dengan kebutuhan. Werther dan Davis dalam Sinambela ( $2016: 218$ )

Dari berbagai definisi diatas dapat disimpulkan bahwa kompensasi merupakan bentuk balas jasa yang diterima seorang karyawan atas jasa atau tenaga nya yang digunakan dalam melaksanakan pekerjaan dalam suatu perusahaan.

Menurut Weihrich,Koontz dalam Sinambela (2016:302) menyatakan bahwa kepuasan merujuk pada pengalaman kesenangan atau kesukaan yang dirasakan oleh seseorang ketika apa yang diinginkannya tercapai.

Menurut Greenberg dan Baron dalam Sinambela (2016 : 302) mengatakan bahwa kepuasan kerja adalah sikap positif atau negative yang dilakukan individu terhadap pekerjaanya.

Menurut Davis dan Newstrom dalam sinambela ( 2016 : 302 ) berpendapat bahwa kepuasan kerja adalah seperangkat perasaan pegawai tentang menyenangkan atau tidaknya pekerjaan mereka dapat dilihat dari diri si pekerja, Pekerjaan yang ada, serta kondisi organisasi Dari beberapa definisi kepuasan kerja diatas dapat disimpulkan bahwa kepuasan kerja adalah bentuk rasa yang dirasakan seseorang terhadap pekerjaan nya, baik rasa senang atau tidak nya terhadap pekerjaan yang mereka lakukan 


\section{Hipotesis}

Menurut Sugiyono (2016:30) pengertian hipotesis adalah jawaban terhadap rumusan masalah yang baru didasarkan pada teori dan didukung oleh penelitian yang relevan, tetapi belum ada pembuktian secara empiris atau faktual. Dengan demikan hipotesis penelitian dapat diartikan sebagai jawaban yang bersifat sementara terhadap masalah penelitian, sampai terbukti melalui data yang terkumpul.

Berdasarkan uraian kerangka pemikiran di atas, maka penulis mencoba mengambil hipotesis dalam pernyataan berikut :

H1 : Diduga Production Emphasis berpengaruh terhadap Kinerja Karyawan.

H2 : Diduga Pengembangan Karier berpengaruh terhadap Kinerja Karyawan.

H3 : Diduga Kompensasi Sosial berpengaruh terhadap Kinerja Karyawan.

H4 : Diduga Production Emphasis dan Pengembangan Karier berpengaruh berpengaruh terhadap Kinerja Karyawan.

H5 : Diduga Production Emphasis dan Kompensasi Sosial memiliki pengaruh terhadap Kinerja Karyawan.

H6 : Diduga Pengembangan Karier dan Kompensasi Sosial berpengaruh terhadap Kinerja Karyawan.

H7 : Diduga Production Emphasis berpengaruh terhadap Kinerja Karyawan dengan di mediasi oleh Kepuasan Kerja.

H8 : Diduga Pengembangan Karier Protean berpengaruh terhadap Kinerja Karyawan dengan di mediasi oleh Kepuasan Kerja.

H9 : Diduga Kompensasi Sosial berpengaruh terhadap Kinerja Karyawan yang di mediasi oleh Kepuasan Kerja.

H10 : Diduga Production Emphasis dan Pengembangan Karier Protean berpengaruh terhadap Kinerja Karyawan dengan di mediasi oleh Kepuasan Kerja.

H11 : Diduga Pengembangan Karier Protean dan Kompensasi Sosial berpengaruh terhadap Kinerja Karyawan dengan di mediasi oleh KepuasanKerja.

H12 : Diduga Production Emphasis dan Kompensasi Sosial berpengaruh terhadap Kinerja Karyawan dengan di mediasi oleh Kepuasan Kerja.

\section{METODE PENELITIAN}

Objek penelitian adalah sasaran ilmiah untuk mendapatkan data dengan tujuan dan kegunaan tertentu tentang sesuatu hal objektif dan realiable tentang suatu hal. Atau dalam kata lain objek penelitian adalah variabel penelitian. Objek dalam penelitian ini yaitu Production Emphasis, Pengembangan Karier Protean, Kompensasi Sosial, Kepuasan Kerja, dan Kinerja Karyawan.

Populasi dalam penelitian ini adalah karyawan produksi PT. Subang Autocomp Indonesia sebanyak 3972 karyawan.

Dalam menetukan sampel yang digunakan dalam penelitian ini, peneliti menggunakan Teknik Probability Sampling yaitu teknik pengambilan sampel yang memberikan peluang yang sama bagi setiap unsur (anggota) populasi untuk dipilih menjadi anggota sampel (Sugiyono, 2016 :122). Sedangkan metode yang digunakan adalah Proportionate Stratified Random Sampling yaitu digunakan bila populasi mempunyai anggota/unsur yang tidak homogen dan berstrata secara proporsional. Penetapan jumlah sampel dalam penelitian ini adalah dengan menggunakan rumus Slovin (Dr. Riduwan dan Dr.Engkos Achmad Kuncoro,2013). Dengan demikian jumlah sampel yang diambil dibulatkan menjadi 100 orang.

Metode yang digunakan adalah Analisis jalur merupakan perluasan dari analisis regresi linier berganda, atau analisis jalur adalah penggunaan analisis regresi untuk menaksir hubungan kausalitas antar variabel (model causal) yang telah ditetapkan sebelumnya berdasarkan teori (Ghozali, 2011:249).

Model Analisis jalur yang digunakan pada peneltian ini adalah Model persamaan satu jalur, pada model ini variable yang diteliti menunjukan hubungan yang sama dengan model regresi berganda,yakni variabel bebas (eksogen) terdiri dari lebih dari satu variabel. dengan variabel moderator terdiri dari satu dan variabel tergantungnya (endogen) hanya satu.

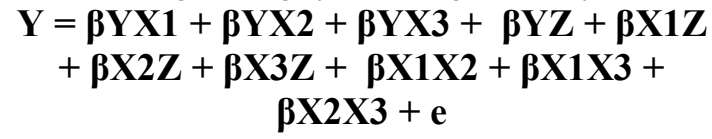




\section{Paradigma Penelitian}

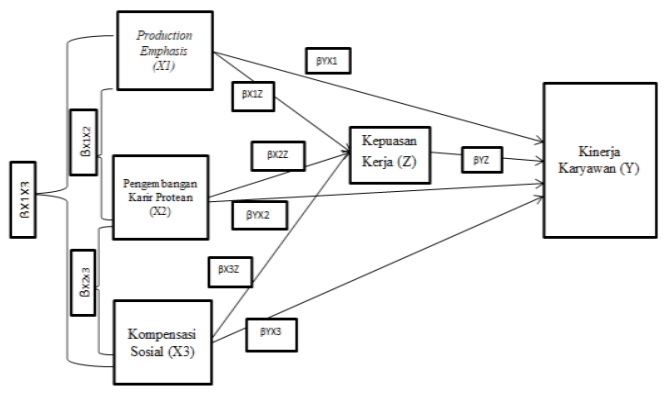

\section{HASIL DAN PEMBAHASAN}

a. Beberapa pengaruh langsung dan tidak langsung ( melalui Y) dan pengaruh total tentang X1 (Production Emphasis), X2 (Pengembangan Karir Protean ), X3 (Kompensasi Sosial) dan Y (Kinerja Karyawan ) terhadap Z (Kepuasan Kerja ) diuraikan sebagai berikut :

1). Pengaruh langsung variabel $X 1$ ( Production Emphasis ) terhadap Z ( Kepuasan Kerja ) $=0,774$.

Pengaruh tidak langsung variabel X1 ( Production Emphasis ) terhadap Y (Kinerja Karyawan) melalui Z ( Kepuasan Kerja $)=$

$0,774+(0,541 \times 0,941)=0,774+0,509$ $=1,283$. Jadi pengaruh total X1 ( Production Emphasis ) terhadap Y ( Kinerja Karyawan ) dengan melalui $\mathrm{Z}$ (Kepuasan Kerja ) sebesar 1,283.

2). Pengaruh langsung variabel X2 ( Pengembangan Karir Protean) terhadap Z $($ Kepuasan Kerja $)=0,886$.

Pengaruh tidak langsung variabel X2 ( Pengembangan Karir Protean ) terhadap Y ( Kinerja Karyawan ) melalui Z ( Kepuasan Kerja $)=0,886+(0,541 \mathrm{x}$ $0,864)=0,886+0,467=1,353$. Jadi pengaruh total X2 ( Pengembangan Karir Protean ) terhadap Y ( Kinerja Karyawan ) dengan melalui $\mathrm{Z}$ ( Kepuasan Kerja ) sebesar 1,353.

3). Pengaruh langsung variabel X3 ( Kompensasi Sosial ) terhadap Z ( Kepuasan Kerja ) $=0,897$.

Pengaruh tidak langsung variabel X3 ( Kompensasi Sosial ) terhadap Y ( Kinerja Karyawan ) melalui Z ( Kepuasan Kerja ) $=0,897+(0,541 \times 0,698)=0,897+0,377$ $=1,274$.

Jadi pengaruh total X3 ( Kompensasi Sosial ) terhadap Y ( Kinerja Karyawan ) dengan melalui Z (Kepuasan Kerja ) sebesar 1,274.

4). Pengaruh langsung variabel X1 ( Production Emphasis) dan X2 ( Pengembangan Karir Protean) Terhadap Z $($ Kepuasan Kerja $)=(0,774+0,886)=$ 1,66

Pengaruh tidak langsung variabel X1( Production Emphasis) dan X2 ( Pengembangan Karir Protean) terhadap Y ( Kinerja Karyawan ) melalui Z ( Kepuasan Kerja $)=$

$1,66+(0,541 \times(0,941+0,864))=1,66+$ $(0,541 \times 1,805)=$

$1,66+0,976=2,636$

Jadi pengaruh total X1 ( Production Emphasis) dan X2 ( Pengembangan Karir Protean ) terhadap Y ( Kinerja Karyawan ) dengan melalui Z (Kepuasan Kerja ) sebesar 2,636.

5). Pengaruh langsung variabel $X 2$ ( Pengembangan Karir Protean ) dan X3 ( Kompensasi Sosial ) Terhadap Z ( Kepuasan Kerja $)=(0,886+0,897)=$ 1,783

Pengaruh tidak langsung variabel X2 ( Pengembangan Karir Protean) dan X3 ( Kompensasi Sosial ) terhadap Y ( Kinerja Karyawan ) dengan melalui Z ( Kepuasan Kerja $)=$

$1,783+(0,541 \times(0,846+0,698))=1,783$ $+(0,541 \times 1,544)=1,783+0,835=2,618$ Jadi pengaruh total X2 (Pengembangan Karir Protean ) dan X3 (Kompensasi Sosia) terhadap Y ( Kinerja Karyawan ) dengan melalui $\mathrm{Z}$ (Kepuasan Kerja ) sebesar 2,618.

6). Pengaruh langsung variabel $\mathrm{X} 1$ (Production Emphasis) dan X3 ( Kompensasi Sosial ) Terhadap Z ( Kepuasan Kerja $)=(0,774+0,897)=$ 1,671

Pengaruh tidak langsung variabel $\mathrm{X} 1$ (Production Emphasis) dan X3 ( Kompensasi Sosial ) terhadap Y ( Kinerja Karyawan ) dengan melalui Z ( Kepuasan Kerja $)=$

$1,671+(0,541 \times(0,941+0,698))=1,671$

$+(0,541 \times 1,639)=$

$1,671+0,915=2,586$

Jadi pengaruh total X1 (Production Emphasis) dan X3 (Kompensasi Sosia) terhadap Y ( Kinerja Karyawan ) dengan melalui Z (Kepuasan Kerja ) sebesar 2,586 
b. Kontribusi X1 ( Production Emphasis) yang secara langsung mempengaruhi $\mathrm{Z}$ ( Kepuasan Kerja ) sebesar 0,774² $=0,5990$ atau $59,90 \%$.

c. Kontribusi X2 ( Pengembangan Karir Protean ) yang secara langsung mempengaruhi Z ( Kepuasan Kerja ) sebesar $0,886^{2}=0,7849$ atau $78,49 \%$.

d. Kontribusi X3 ( Kompensasi Sosial) yang secara langsung mempengaruhi $\mathrm{Z}$ ( Kepuasan Kerja ) sebesar 0,897 $=0,8046$ atau $80,46 \%$.

e. Kontribusi Y ( Kinerja Karyawan ) yang secara langsung mempengaruhi Z ( Kepuasan Kerja ) sebesar 0,541 $2=0,2926$ atau $29,26 \%$

f. Kontribusi X1 ( Production Emphasis), X2 ( Pengembangan Karir Protean ), X3 ( Kompensasi Sosial ) dan Y ( Kinerja Karyawan ) secara simultan yang langsung mempengaruhi Z ( Kepuasan Kerja ) sebesar $R^{2}=0,671$ atau $67 \%$. Sisanya sebesar $33 \%$ dipengaruhi faktor - faktor lain yang tidak dapat dijelaskan dalam penelitian.

g. Kontribusi X1 ( Production Emphasis) yang secara langsung mempengaruhi Y ( Kinerja Karyawan ) sebesar $0,941^{2}=$ 0,8854 atau $88,54 \%$

h. Kontribusi X2 ( Pengembangan Karir Protean ) yang secara langsung mempengaruhi Y ( Kinerja karyawan ) sebesar $0,864^{2}=0,7464$ atau $74,64 \%$.

i. Kontribusi X3 (Kompensasi Sosial) yang secara langsung mempengaruhi $\mathrm{Y}$ ( Kinerja Karyawan ) Sebesar $0,698^{2}=$ 0,4872 atau $48,72 \%$.

j. Kontribusi X1 ( Production Emphasis ), X2 ( Pengembangan Karir Protean ), dan X3 ( Kompensasi Sosial ) yang secara simultan mempengaruhi Y ( Kinerja Karyawan ) sebesar $R^{2}=0,942$ atau $94,2 \%$.

\section{Hasil Uji Parsial}

1. Dari penghitungan berdasarkan SPSS 24, diketahui bahwa hasil uji $\mathrm{T}$ diperoleh $\mathrm{t}_{\text {hitung }}$ untuk Production Emphasis (X1) sebesar 19.215. Hal tersebut menunjukan bahwa 19.215 $\mathrm{t}_{\text {hitung }}>1.660 . \mathrm{t}_{\text {tabel. }}$. Dengan demikian maka Ho diterima dan $\mathrm{Ha}$ ditolak (berpengaruh). Pengaruh Production Emphasis (X1) bernilai positif karena koefisien regresinya bernilai positif senilai 19.215 terhadap kinerja karyawan (Y) pada PT Subang Autocomp Indonesia. Sehingga dapat disimpulkan bahwa Production Emphasis berpengaruh secara signifikan terhadap Kinerja Karyawan pada PT Subang Autocomp Indonesia.

2. Dari penghitungan berdasarkan SPSS 24, diketahui bahwa hasil uji $\mathrm{T}$ diperoleh $\mathrm{t}_{\text {hitung }}$ untuk Pengembangan Karir Protean (X2) sebesar 14.982. Hal tersebut menunjukan bahwa $14.982 t_{\text {hitung }}>1.660 . t_{\text {tabel. }}$. Dengan demikian maka Ho diterima dan $\mathrm{Ha}$ ditolak (berpengaruh). Pengaruh Pengembangan Karir Protean (X2) bernilai positif karena koefisien regresinya bernilai positif senilai 8.932 terhadap kinerja karyawan (Y) pada PT Subang Autocomp Indonesia. Sehingga dapat disimpulkan bahwa Pengembangan Karir Protean berpengaruh secara signifikan terhadap Kinerja Karyawan pada PT Subang Autocomp Indonesia.

3. Dari penghitungan berdasarkan SPSS 24, diketahui bahwa hasil uji $\mathrm{T}$ pada tabel 4.20 diperoleh $t_{\text {hitung }}$ untuk Kompensasi Sosial (X3) sebesar 8.934. Hal tersebut menunjukan bahwa $8.934 \quad t_{\text {hitung }}>$

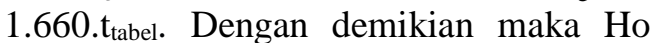
diterima dan Ha ditolak (berpengaruh). Pengaruh Kompensasi Sosial (X3) bernilai positif karena koefisien regresinya bernilai positif senilai 21.113 terhadap kinerja karyawan (Y) pada PT Subang Autocomp Indonesia. Sehingga dapat disimpulkan bahwa Kompensasi Sosial berpengaruh secara signifikan terhadap Kinerja Karyawan pada PT Subang Autocomp Indonesia.

\section{Hasil Uji Simultan}

Berdasarkan tabel 4.27 diketahui bahwa hasil perhitungan uji $\mathrm{F}_{\text {hitung }}$ sebesar 514.727 lebih besar dari $F_{\text {tabel }} 3,09$. Dengan demikian dapat disimpulkan bahwa $\mathrm{F}_{\text {hitung }} 514.727>\mathrm{F}_{\text {tabel }}$ 3,09, artinya $\mathrm{H}_{0}$ diterima dan $\mathrm{H}_{\mathrm{a}}$ ditolak. Sehingga dapat disimpulkan bahwa Production Emphasis (X1), Pengembangan Karir Protean (X2) dan Kompensasi Sosial (X3) secara simultan berpengaruh signifikan terhadap Kinerja Karyawan (Y) pada PT Subang Autocomp Indonesia. 
Pembahasan

Pada BAB sebelumnya, telah dikemukakan bahwa ada beberapa hipotesis yang diajukan. Maka, berikut adalah hasil pengujian terhadap hipotesis sesuai dengan pendekatan analisis jalur :

1. Pengaruh Production Emphasis (X1) terhadap Kinerja Karyawan (Y)

Dari penghitungan berdasarkan SPSS 24, diketahui bahwa bahwa hasil uji $\mathrm{T}$ diperoleh thitung untuk Production Emphasis (X1) sebesar 19.215. Hal tersebut menunjukan bahwa 19.215 thitung $>$ 1.660.ttabel. Sehingga, dapat dikatakan bahwa ada pengaruh langsung yang positif dan signifikan antara variabel Production Emphasis (X1) terhadap Kinerja Karyawan(Y).

2. Pengaruh Pengembangan Karir Protean (X2) terhadap Kinerja Karyawan (Y)

Dari penghitungan berdasarkan SPSS 24, diketahui bahwa hasil uji $\mathrm{T}$ diperoleh $\mathrm{t}_{\text {hitung }}$ untuk Pengembangan Karir Protean (X2) sebesar 8.932. Hal tersebut menunjukan bahwa 8.932 thitung > 1.660. $\mathrm{t}_{\text {tabel }}$ Sehingga, dapat dikatakan bahwa ada pengaruh langsung yang positif dan signifikan antara variabel Pengembangan Karir Protean (X2) terhadap Kinerja Karyawan (Y).

3. Pengaruh Kompensasi Sosial (X3) terhadap Kinerja Karyawan (Y)

Dari penghitungan berdasarkan SPSS 24, diketahui bahwa hasil uji T pada tabel 4.20 diperoleh thitung untuk Kompensasi Sosial (X3) sebesar 21.113. Hal tersebut menunjukan bahwa 21.113 $\mathrm{t}_{\text {hitung }}>1.660 . \mathrm{t}_{\text {tabel. }}$ Sehingga, dapat dikatakan bahwa ada pengaruh langsung yang positif dan signifikan antara variabel Kompensasi Sosial (X3) terhadap Kinerja Karyawan(Y).

4. Pengaruh Production Emphasis (X1) dan Pengembangan Karir Protean (X2) terhadap Kinerja Karyawan (Y).

Dari nilai korelasi ( $\mathrm{R}$ ) atau hubungan variabel X1 ( Production Emphasis ) dan X2 ( Pengembangan Karir Protean) terhadap Y Kinerja Karyawan adalah sebesar 0,970. Dan dikategorikan kedalam kategori sangat kuat.
5. Pengaruh Pengembangan Karir Protean (X2) dan Kompensasi Sosial (X3) terhadap Kinerja Karyawan (Y)

Dan untuk nilai korelasi ( $\mathrm{R}$ ) atau hubungan antara variabel X2 (Pengembangan Karir Protean ) dan X3 ( Kompensasi Sosial) terhadap Kinerja adalah 0,846 dimana angka tersebut masuk kedalam kategori sangat kuat.

6. Pengaruh Production Emphasis (X1) dan Kompensasi Sosial (X3) terhadap Kinerja Karyawan (Y)

Selanjutnya untuk nilai korelasi ( $\mathrm{R}$ ) hubungan antara variabel X1 ( Production Emphasis ) dan X3 ( Kompensasi Sosial ) terhadap Y ( Kinerja Karyawan ) menghasilkan angka sebesar 0,970. Dimana angka tersebut masuk kedalam kategori sangat kuat.

7. Pengaruh Production Emphasis (X1), Pengembangan Karir Protean (X2) dan Kompensasi Sosial (X3) terhadap Kinerja Karyawan (Y).

Dari penghitungan berdasarkan SPSS 24, diketahui bahwa hasil perhitungan uji $F_{\text {hitung }}$ sebesar 514.727 lebih besar dari $F_{\text {tabel }}$ 3,09. Dengan demikian dapat disimpulkan bahwa $\mathrm{F}_{\text {hitung }}$ $514.727>F_{\text {tabel }}$ 3,09 Sehingga dapat disimpulkan bahwa Production Emphasis (X1), Pengembangan Karir Protean (X2), dan Kompensasi Sosial (X3) secara simultan berpengaruh signifikan terhadap Kinerja Karyawan $(\mathrm{Y})$

8. Pengaruh Production Emphasis (X1) terhadap Kinerja Karyawan (Y) dengan dimediasi oleh Kepuasan Kerja (Z)

Dari hasil perhitungan SPSS versi 24, diketahui bahwa Pengaruh tidak langsung variabel X1 ( Production Emphasis ) terhadap Y (Kinerja Karyawan) melalui Z ( Kepuasan Kerja $)=$ $0,774+(0,541 \times 0,941)=0,774+0,509$ $=1,283$. Sehingga dapat dikatakan memiliki pengaruh yang signifikan karena nilai pengaruh tidak langsung $>$ dari pada nilai pengaruh langsung $\mathrm{X} 1 \mathrm{ke} \mathrm{Z}$.

9. Pengaruh Pengembangan Karir Protean (X2) terhadap Kinerja Karyawan (Y) dengan dimediasi oleh Kepuasan Kerja (Z)

Dari hasil perhitungan SPSS versi 24, diketahui bahwa Pengaruh tidak langsung 
variabel X2 ( Pengembangan Karir Protean ) terhadap Y ( Kinerja Karyawan ) melalui Z ( Kepuasan Kerja $)=0,886+($ $0,541 \times 0,864)=0,886+0,467=1,353$. Sehingga dapat dikatakan memiliki pengaruh yang signifikan karena nilai pengaruh tidak langsung $>$ dari pada nilai pengaruh langsung X2 ke Z.

10. Pengaruh Kompensasi Sosial (X3) terhadap Kinerja Karyawan (Y) dengan dimediasi oleh Kepuasan Kerja (Y)

Dari hasil perhitungan SPSS versi 24, diketahui bahwa Pengaruh tidak langsung variabel X3 ( Kompensasi Sosial ) terhadap Y ( Kinerja Karyawan ) melalui $\mathrm{Z}($ Kepuasan Kerja $)=0,897+(0,541 \mathrm{x}$ $0,698)=0,897+0,377=1,274$. Sehingga dapat dikatakan memiliki pengaruh yang signifikan karena nilai pengaruh tidak langsung > dari pada nilai pengaruh langsung X3 ke Z.

11. Pengaruh Production Emphasis (X1) dan Pengembangan Karir Protean (X2) terhadap Kinerja Karyawan (Y) dengan dimediasi oleh Kepuasan Kerja (Z)

Dari hasil perhitungan SPSS versi 24, diketahui bahwa Pengaruh tidak langsung variabel X1( Production Emphasis) dan X2 ( Pengembangan Karir Protean) terhadap Y ( Kinerja Karyawan ) melalui Z $($ Kepuasan Kerja $)=$

$1,66+(0,541 \times(0,941+0,864))=1,66+$ $(0,541 \times 1,805)=$

$1,66+0,976=2,636$. Sehingga dapat dikatakan memiliki pengaruh yang signifikan karena nilai pengaruh tidak langsung > dari pada nilai pengaruh langsung X1 dan X2 ke Z.

12. Pengaruh Pengembangan Karir Protean (X2) dan Kompensasi Sosial (X3) terhadap Kinerja Karyawan (Y) dengan dimediasi oleh Kepuasan Kerja (Z)

Dari hasil perhitungan SPSS versi 24, diketahui bahwa Pengaruh tidak langsung variabel X1 (Production Emphasis) dan X3 ( Kompensasi Sosial ) terhadap Y ( Kinerja Karyawan ) dengan melalui Z $($ Kepuasan Kerja $)=$

$1,671+(0,541 \times(0,941+0,698))=1,671$ $+(0,541 \times 1,639)=1,671+0,915=$ 2,586 . Sehingga dapat dikatakan memiliki pengaruh yang signifikan karena nilai pengaruh tidak langsung $>$ dari pada nilai pengaruh langsung X2 dan X3 ke Z.

\section{SIMPULAN DAN SARAN}

1. Production Emphasis (X1) memiliki pengaruh langsung yang positif dan signifikan terhadap Kinerja Karyawan (Y). Berarti dengan adanya Production Emphasis dalam sebuah perusahaan dapat memicu kinerja karyawan untuk menghasilkan kinerja yang baik, serta peningkatan Production Emphasis akan meningkatkan Kinerja Karyawan.

2. Pengembangan Karir Protean (X2) memiliki pengaruh langsung yang positif dan signifikan terhadap Kinerja Karyawan (Y). Berarti dengan adanya Pengembangan Karir Protean dalam sebuah perusahaan dapat memicu kinerja karyawan untuk menghasilkan kinerja yang baik, serta peningkatan Pengembangan Karir Protean akan meningkatkan Kinerja Karyawan.

3. Kompensasi Sosial (X3) memiliki pengaruh langsung yang positif dan signifikan terhadap Kinerja Karyawan (Y). Berarti dengan adanya Kompensasi Sosial dalam sebuah perusahaan terbukti secara ilmiah dapat memicu kinerja karyawan untuk menghasilkan kinerja yang baik, serta peningkatan Kompensasi Sosial akan meningkatkan Kinerja Karyawan.Perusahaan yang memiliki kepastian masa jabatan yang pasti akan meningkatkan kinerja karyawan.

4. Production Emphasis (X1) dan Pengembangan Karir Protean ( X2) memiliki hubungan sangat kuat terhadap Kinerja Karyawan (Y). Dengan adanya dorongan dan fasilitas yang memadai untuk berkembang dapat meningkatkan kinerja karyawan.

5. Pengembangan Karir Protean (X2) dan (X3) Kompensasi Sosial memiliki hubungan sangat kuat terhadap Kinerja Karyawan (Y). Perusahaan yang menerapkan pengembangan karir protean yaitu karir yang didasarkan atas dorongan karyawan itu sendiri dan kompensasi sosial dapat meningkatkan kinerja karyawan.

6. Production Emphasis (X1) dan Kompensasi Sosial (X3) memiliki hubungan sangat kuat terhadap Kinerja Karyawan (Y). Karyawan yang memiliki dorongan untuk melaksanakan pekerjaan 
nya dan didukung oleh adanya kepastian jabatan yang mereka dapatkan dapat meningkatkan kinerja karyawan.

7. Production Emphasis (X1), Pengembangan Karir Protean (X2), dan Kompensasi Sosial (X3) secara simultan berpengaruh signifikan terhadap Kinerja Karyawan (Y). Baerarti bahwa secara bersama - sama Production Emphasis , Pengembangan Karir Protean, dan Kompensasi Sosial dapat dibuktikan mampu meningkatkan Kinerja Karyawan. Perusahaan yang menerapkan dorongan kepada karyawan, memiliki pengembangan karir yang didasarkan dari individu karyawan nya dan memberikan kepastian masa jabatan kepada karyawannya, akan membuat karyawan puas sehingga mampu meningkatkan kinerja karyawan.

8. Production Emphasis (X1) memiliki pengaruh yang signifikan terhadap Kinerja Karyawan (Y) dengan dimediasi oleh Kepuasan Kerja (Z). perusahaan yang memberikan dorongan kepada karyawannya untuk melaksanakan pekerjaan nya, akan memberikan kepuasan tersendiri kepada karyawan sehingga menghasilkan kinerja yang baik.

9. Pengembangan Karir Protean (X2) memiliki pengaruh yang signifikan terhadap Kinerja Karyawan (Y) dengan dimediasi oleh Kepuasan Kerja (Z). Perusahaan yang menerapkan pengembangan karir protean dapat memberikan kepuasan kepada karyawan sehingga karyawan mampu memberikan kinerja yang baik.

10. Pengaruh Kompensasi Sosial (X3) memiliki pengaruh yang signifikan terhadap Kinerja Karyawan (Y) dengan dimediasi oleh Kepuasan Kerja (Y). Dengan adanya kepastian masa jabatan dapat memberikan kepuasan pada karyawan, sehingga mereka mampu menghasilkan kinerja yang baik.

11. Pengaruh Production Emphasis (X1) dan Pengembangan Karir Protean (X2) memiliki pengaruh yang signifikan terhadap Kinerja Karyawan (Y) dengan dimediasi oleh Kepuasan Kerja (Z). Dua variabel diatas memiliki hubungan yang sangat kuat dan perusahaan yang menerapkan dua variabel tersebut akan memberikan kepuasan kerja pada karyawan yang mampu meningkatkan kinerja karyawan.

12. Pengaruh Pengembangan Karir Protean (X2) dan Kompensasi Sosial (X3) memiliki pengaruh yang signifikan terhadap Kinerja Karyawan (Y) dengan dimediasi oleh Kepuasan Kerja (Z). Dua variabel tersebut memiliki hubungan yang sangat kuat, yang memberikan kepuasan kerja bila di terapkan dalam perusahaan yang dapat meningkatkan kinerja Karyawan.

\section{SARAN}

1. Perusahaan disarankan untuk menanamkan pengetahuan kepada karyawan bahwa Quality Is Number One. Mengingat produk yang diproduksi merupakan produk yang akan digunakan dalam sebuah kendaraan yang jika pengerjaan nya tidak mengutamakan kualitas dapat menimbulkan customer klaim. Dan dapat membahayakan nyawa customer.

2. Perusahaan dapat meningkatkan target produksi untuk memicu semangat karyawan, sehingga mampu mencapai target DPM.

3. Bagi pemimpin diharapkan untuk mempertajam upaya mengarahkan karyawan melalui Production Emphasis untuk membangkitkan semangat karyawan.

4. Bagi pihak manajemen perusahaan dihapkan untuk dapat meningkatkan transparansi informasi pengembangan karir dan fasilitas - fasilitas serta waktu yang dapat menunjang karyawan dalam mengembangkan kemampuannya.

5. Bagi Peneliti selanjutnya lebih baik melakukan penelitian lebih lanjut lagi mengenai faktor - faktor yang dapat mempengaruhi Kinerja Karyawan. Peneliti selanjutnya sebaiknya tidak hanya menggunakan variabel yang sudah digunakan dalam penelitian ini tetapi bisa memperbanyak indicator lainnya yang dapat mempengaruhi kinerja karyawan, seperti tingkat pendidikan, tingkat trunover karyawan, kompetensi karyawan, dan sebagainya serta diharapkan peneliti selanjutnya bisa menambah referensi penelitian ini. 


\section{REFERENSI}

Distyawaty, D., Pengaruh Kompetensi dan Pengembangan Karir terhadap Kinerja Aparatur Pengawas Inspektorat Daerah Provinsi Sulawesi Tengah. Katalogis, 5(4).

Ghozali, I., 2006. Aplikasi analisis multivariate dengan program SPSS. Badan Penerbit Universitas Diponegoro.

Lestari, O.N.B. and Nugraheni, R., 2015. Pengaruh Kepemimpinan, Motivasi Kerja, Dan Lingkungan Kerja Fisik Terhadap Kinerja Karyawan (Studi Kasus Pada PT Luxindo Nusantara Kota Semarang) (Doctoral dissertation, Fakultas Ekonomika dan Bisnis).

Prasetiyo, S., 2014. Pengaruh Gaya Kepemimpinan dan Kompensasi terhadap Kinerja karyawan dengan Kepuasan kerja sebagai Variabel Intervening (studi pada Hotel berbintang di Yogyakarta). Skripsi. Fakultas Ekonomi Universitas Negeri Yogyakarta.

Rahmawati, S. and Supartha, W.G., 2015. Pengaruh Iklim Organisasi Dan Motivasi Kerja Pada Kepuasan Kerja Pegawai Balai Wilayah Sungai BaliPenida. E-Jurnal Manajemen, 4(11)

Riduwan, K.E. and Kuncoro, E.A., 2013. Cara Mudah Menggunakan dan Memakai Path Analysis (Analisis Jalur). Bandung (ID): Alfabeta.

Sinambela, L.P., 2016. Manajemen sumber daya manusia. Jakarta: Bumi Aksara.

Poltak, S.L., 2016. Manajemen Sumber Daya Manusia.

Soetopo, H., 2012. Perilaku organisasi: teori dan praktik di bidang pendidikan. PT Remaja Rosdakarya.

Sugiyono, P., Dr. 2010. Metode Penelitian Kuantitatif, Kualitatif, dan $R \& D$. Bandung: CV Alfabeta.

Sugiyono, M.P.K., 2013. Kualitatif, dan Kombinasi (Mixed Methods). Bandung: Alfabeta.
Afriani, I., Indarti, S. and Garnarsih, R.L., PENGARUH

PROMOSI

JABATAN DAN IKLIM

ORGANISASI TERHADAP

KEPUASAN KERJA DAN

PRESTASI KERJA PEGAWAI

PADA

BADAN

PENGEMBANGAN

SUMBERDAYA MANUSIA

PROVINSI RIAU. Jurnal Tepak

Manajemen Bisnis, 11(3).

Ma'mun, H. F., \& Amruloh, D. A. G. (2019). Kreativitas dan Psychological Capital Pengusaha Batu Templek di Kabupaten Purwakarta. Eqien: Jurnal Ekonomi dan Bisnis, 6(1), 1-11.

Amruloh, D. A. G. (2017). (the 3rd Icbess 2016-Proceeding Kartika Discovery Hotel Bali, August 1011, 2016) Entrepreneur Orientation in Islamic Perspective. Eqien: Jurnal Ekonomi dan Bisnis, 4(1).

Nusannas, I. S. (2018). Pengaruh Pendidikan Kewirausahaan dan Lingkungan Keluarga terhadap Minat Wirausaha (Studi Kasus Mahasiswa Perguruan Tinggi Ekonomi di Purwakarta). Eqien: Jurnal Ekonomi dan Bisnis, 5(2), 90-99.

Hidayat, S., 2018. Pengaruh Praktik Manajemen Sumber Daya Manusia terhadap Kinerja Karyawan di PT. Indo-rama Synthetics Tbk. Divisi Spun Yarns. Eqien: Jurnal Ekonomi dan Bisnis, 5(1), pp.57-67.

Amruloh, D.A.G., 2016. Kontruksi Hubungan Orientasi Wirausaha dengan Kinerja USAha (Studi Kasus pada UMKM Keramik Plered Purwakarta). Eqien: Jurnal Ekonomi dan Bisnis, 3(1), pp.2329. 
Amruloh, D.A.G., 2016. Kontruksi Hubungan Orientasi Wirausaha dengan Kinerja USAha (Studi Kasus pada UMKM Keramik Plered Purwakarta). Eqien: Jurnal Ekonomi dan Bisnis, 3(1), pp.2329.

Imbari, S., 2018. Pengaruh Kualitas Pelayanan dan Kepuasan terhadap Loyalitas (Studi pada Nasabah Tabungan Bank Bca Cabang Purwakarta). Eqien: Jurnal Ekonomi dan Bisnis, 5(1), pp.4050. 